\title{
MEKANISME TRANSMISI HARGA INTERNASIONAL DALAM RANGKA PENETAPAN KEBIJAKAN HARGA OLEH PEMERINTAH TERHADAP BEBERAPA KOMODITAS HASIL PERTANIAN TERTENTU
}

\author{
Didi Nuryadin, Rini Dwi Astuti, Ardito Bhinadi \\ Fakultas Ekonomi dan Bisnis, UPN Veteran Yogyakarta, \\ Jalan SWK 104, Condongcatur, Depok, Sleman, Daerah Istimewa Yogyakarta \\ Email Korespondensi: didinuryadin@gmail.com
}

Naskah Diterima: Januari 2016; Disetujui: April 2016

\begin{abstract}
This study aimed to analyze the mechanism of transmission of international prices in the context of preparing the government's policy of controlling prices through the pricing of certain agricultural commodities. This price control in order to ensure stability of prices of agricultural commodities so as to support and ensure the economic stability. The analytical tool used is regression to the data period used was May 2009 to December 2013. The results showed that the increase in retail price increases in producer prices which indicates that the market red peppers, chicken meat and fresh fish are not integrated perfectly. Variation changes in retail prices is a source of variation and the producer price changes have a significant relationship between producer prices at retail prices. Changes in retail prices is not transmitted completely to the producer price which the retail price increases pushed up producer prices.
\end{abstract}

Keywords: the transmission mechanism, international prices, domestic prices, pricing policies, agricultural commodities

JEL Classification: Q13, Q18, L11, F40, E31, E23, D4

Abstrak: Penelitian ini bertujuan untuk menganalisis mekanisme transmisi harga internasional dalam rangka penyusunan kebijakan pemerintah dalam pengendalian harga melalui penetapan harga komoditas pertanian tertentu. Pengendalian harga ini dalam rangka menjamin stabilitas harga komoditas pertanian sehingga dapat menunjang dan menjamin stabilitas perekonomian masyarakat secara nasional. Alat analisis yang digunakan adalah regresi dengan periode data yang digunakan adalah Mei 2009 s.d Desember 2013. Hasil penelitian menunjukkan bahwa kenaikan harga eceran meningkatkan harga di tingkat produsen yang mengindikasikan bahwa pasar cabai merah, daging ayam ras, dan ikan segar tidak terintegrasi dengan sempurna. Variasi perubahan harga eceran merupakan sumber variasi perubahan harga produsen dan memiliki hubungan yang signifikan antara harga di tingkat produsen dengan harga eceran. Perubahan harga eceran tidak tertransmisikan secara sempurna ke harga produsen dimana kenaikan harga eceran mendorong kenaikan harga produsen.

Kata kunci: mekanisme transmisi, harga internasional, harga domestik, kebijakan harga, komoditas pertanian

Klasifikasi JEL: Q13, Q18, L11, F40, E31, E23, D4 


\section{PENDAHULUAN}

Salah satu masalah utama dalam perdagangan dalam negeri adalah terkait dengan ketidakstabilan harga komoditas hasil pertanian. Fenomena kenaikan harga komoditas pertanian, khususnya pangan, pada momenmomen tertentu seperti saat bulan Ramadhan dan hari-hari besar lainnya di Indonesia selalu terjadi berulang setiap tahun. Selain itu, inflasi juga akan meningkat terus jika pemerintah tidak dapat mengendalikan harga komoditas pertanian. Fenomena inflasi akibat kenaikan harga komoditas pertanian bahkan tetap terjadi tanpa adanya sentimen dari kondisi ekonomi global. Jika pun ada sentimen eksternal, maka potensi risiko inflasi akan semakin kompleks.

Selama ini Pemerintah melalui Kementerian Perdagangan terus mendorong pengendalian dan pengawasan ketersediaan pasokan untuk memastikan kestabilan harga baik di tingkat konsumen (masyarakat) maupun produsen baik melalui penetapan kebijakan harga, operasi pasar, pengendalian ekspor dan impor maupun regulasi lainnya yang ditujukan untuk tetap menjaga tingkat kestabilan harga di dalam negeri.

Salah satu peran Pemerintah yang diperlukan untuk melengkapi (komplemen) dan mengkoreksi mekanisme pasar yang terjadi terkait dengan harga komoditas pertanian adalah dengan penetapan kebijakan harga (Pasal 26 Undang-undang Nomor 7 Tahun 2014). Penetapan kebijakan harga adalah pedoman Pemerintah dalam menetapkan harga di tingkat produsen dan harga di tingkat konsumen.

Pemahaman secara rinci terhadap perkembangan situasi dan gerak pasar merupakan persyaratan penting untuk membangun keunggulan komparatif dan kompetitif agribisnis. Ketersediaan data dan informasi yang mutakhir yang terkait dengan harga, ekspor, impor, penawaran-permintaan dan indikator ekonomi dan perdagangan lainnya serta berbagai peristiwa sangat dibutuhkan. Informasi tersebut akan menjadi dasar dalam melakukan kajian pasar (market intelligence), pengambilan kebijakan/ penetapan peraturan, pembinaan oleh instansi pembina serta sebagai pertimbangan dalam mengambil langkah bisnis yang tepat bagi para pelaku usaha.
Produk pertanian seperti beras, karet, kopi, kakao, gula, teh, jagung, dan kedelai sudah menjadi komoditi utama dalam perdagangan internasional. Harga-harga pasar dalam negeri maupun harga-harga pasar luar negeri (internasional) yang terjadi dari transaksitransaksi perdagangan secara umum berlaku di bawah kaidah-kaidah penawaran dan permintaan. Harga-harga yang berkembang di bursa pasar internasional memberikan pengaruh yang cukup besar terhadap pasar harga dalam negeri. Pada perdagangan dalam negeri, harga komoditi tersebut pada umumnya ditentukan oleh para pedagang. Sedangkan dalam kenyataannya, petani sebagai produsen komoditas pertanian kurang mampu dalam menciptakan bargaining position dalam penciptaan harga. Petani selalu kurang diuntungkan sebagai produsen dalam rantai perdagangan baik lokal maupun internasional.

Terkait dengan latar belakang tersebut, maka diperlukan suatu tinjauan akademis secara mendalam terkait dengan mekanisme transmisi harga internasional dalam rangka penyusunan kebijakan pemerintah dalam pengendalian harga melalui penetapan harga komoditas pertanian tertentu. Pengendalian harga ini dalam rangka menjamin stabilitas harga komoditas pertanian sehingga dapat menunjang dan menjamin stabilitas perekonomian masyarakat secara nasional.

\section{Kajian Literatur}

Lee, Hyun-Hoon dan Park, Cyn-Young (2013) mengemukakan bahwa inflasi harga pangan dalam negeri sangat terkait dengan nilai dari inflasi harga pangan global (indeks harga makanan FAO). Menariknya, fluktuasi limpahan dari global untuk harga pangan dalam negeri tampaknya kontemporer. Gerakan tingkat inflasi harga pangan nasional dan fluktuasi sangat terkait dengan tingkat inflasi harga pangan intra dan ekstra-regional dan fluktuasi masing-masing. Selajutnya hal ini juga menunjukkan bahwa inflasi harga pangan global mempengaruhi pasar makanan nasional di seluruh wilayah, tetapi dengan jeda waktu berbeda. Selain temuan penelitian juga menunjukkan bahwa tingkat pertumbuhan ekonomi yang lebih tinggi, impor bahan makanan yang lebih besar dari porsi seluruh barang impor, peningkatan impor bahan makanan yang lebih kecil di bandingkan barang 
impor lain, apresiasi mata uang lokal, stabilitas politik yang lebih baik, dan tingkat pendapatan yang lebih tinggi. Semua hal tersebut mengarah untuk menurunkan inflasi harga pangan dalam negeri. Sementara dalam hal fluktuasi harga pangan, hanya tingkat pertumbuhan ekonomi yang berpengaruh, dimana negara-negara dengan ekonomi yang lebih tinggi tingkat pertumbuhannya memiliki fluktuasi harga pangan nasional yang lebih rendah.

Baltzer, Kenneth (2013) memperoleh kesimpulam bahwa dari ke empat belas negara yang diteliti dapat dikategorikan menurut status perdagangan untuk menghasilkan prediksi mengenai pola transmisi harga. Keempat kategori tersebut adalah: 1. Pedagang bebas (terintegrasi dan ekonomi pertanian yang terbuka), Brazil dan Afrika Selatan diperkirakan akan menunjukkan tingkat yang relatif besar pada transmisi harga. 2. stabilisator ekspor (China, India, dan Vietnam) merupakan eksportir beras, dan negara-negara ini memiliki kontrol yang efektif terhadap ekspor. 3. Importir: dari empat belas negara dalam sampel, Bangladesh, Mesir, Kenya, Mozambik, dan Senegal yang konsisten tergantung pada impor makanan pokok mereka. 4. Terisolasi (Ethiopia, Nigeria, Malawi, Zambia) memiliki ruang yang sangat kecil untuk terintegrasi dengan pasar sereal internasional dan sebagian besar mandiri dalam pokok utama mereka. Kemudian diketahui bahwa integrasi pasar menunjukkan bahwa guncangan lokal dapat diredam di pasar global melalui transmisi harga internasional. Jika guncangan lokal besar, ini akan melibatkan perubahan substansial dalam pola perdagangan. Pada contoh Ethiopia menunjukkan bahwa transmisi harga crosskomoditas antara bahan makanan poko yang berbeda bisa menjadi saluran penting untuk transmisi harga internasional juga.

Selanjutnya penelitian yang dilakukan oleh World Bank (2012) memperoleh kesimpulan bahwa transmisi dianggap penting karena transmisi harga pangan internasional untuk harga domestik sangat penting untuk mengejar keunggulan berbasis komparatif, produksi pertanian yang berkelanjutan, dan untuk memastikan produksi dalam negeri merespon kelangkaan pangan global. Peningkatan dalam volatilitas harga pangan internasional, perlu perhatian besar, namun mencegah transmisi melalui harga internasional untuk melindungi konsumen adalah kontraproduktif. Oleh karena itu langkah yang perlu dilakukan untuk meningkatkan transmisi harga yaitu pertama, negara harus berinvestasi dalam infrastruktur pasar domestik dan menyelaraskan kebijakan untuk lebih mengintegrasikan pasar domestik dan internasional. Kedua, pembuat kebijakan harus mengejar kebijakan perdagangan terbuka untuk mendapatkan kembali kepercayaan dari banyak negara di pasar internasional. Dan ketiga, negara harus memperkuat jaring pengaman mereka dan menggunakannya secara efektif berfokus pada masyarakat miskin dan rentan untuk mengurangi dampak kenaikan harga, sementara memungkinkan harga domestik naik untuk menginduksi respon suplai makanan.

Dalam kaitannya dengan tahap produksi pangan, maka peneltian yang dilakukan oleh Weinhagen, Jonathan C. (2012), menjelaskan analisis transmisi harga melalui tiga tahap produksi pangan yang menunjukkan perbedaan besar dalam transmisi harga dari produsen makanan untuk makanan yang dikonsumsi di rumah dengan makanan yang dikonsumsi jauh dari rumah peningkatan di berbagai PPI yang berhubungan dengan makanan menyebabkan kenaikan CPI untuk makanan yang dikonsumsi di rumah tetapi tidak untuk CPI pada makanan yang dikonsumsi jauh dari rumah. Sedangkan Minot, Nicholas. 2011 mengemukakan bahwa Tingkat kenaikan harga tampaknya terkait dengan tingkat daya jual. Komoditas yang memiliki nilai perdagangan lebih tinggi akan lebih erat terkait dengan pasar internasional, sehingga harga domestik komoditas tersebut mengikuti lonjakan harga dunia. Sementara komoditas yang kurang banyak diperdagangkan di pasar internasional mengalami peningkatan harga yang lebih kecil di pasar Afrika. Selain bahwa harga internasional makanan biji-bijian memiliki beberapa efek pada pasar Afrika yaitu untuk beras dan untuk tingkat yang lebih rendah yaitu jagung, tetapi efeknya biasanya tenggelam oleh efek dominan yaitu guncangan pasokan domestik yang berhubungan dengan cuaca. Lonjakan harga dunia pada tahun 2007-2008 itu lebih jelas merupakan transmisi karena (1) itu adalah kejutan besar, (2) itu didampingi oleh biaya transportasi naik tajam, (3) upaya oleh 
negara-negara Afrika untuk melarang ekspor gandum berkontribusi harga pangan meningkat di negara-negara tetangga, dan (4) faktor lokal dan pembatasan perdagangan swasta memperburuk kenaikan harga di beberapa negara.

Penelitian lain, diantaranya dilakukan oleh Keats, Sharada. dkk. (2010) menemukan bahwa ketika harga sereal/bahan makanan pokok dunia melonjak pada 2007 hingga 2008, ada yang berhubungan dengan kenaikan di pasar domestik di banyak negara berkembang. Namun transmisi Harga tidak terjadi secara merata, di sebagian besar negara di Asia harga beras naik namun lebih kecil dari kenaikan harga di pasar dunia. Sementara di Afrika terjadi kenaikan harga jagung yang sangat tinggi dan jauh lebih tinggi daripada kenaikan yang terjadi di pasar dunia. Namun hal ini tidak berkorelasi dengan harga internasional. Kemungkinan hal ini adalah akibat dari insiden faktor lokal, dan inflasi impor dari kenaikan harga minyak. Sebagian besar pemahaman tentang dampak dari lonjakan harga telah dihasilkan oleh model yang mengasumsikan tingkat transmisi dari harga internasional untuk harga domestik. Namun, karena transmisi umumnya tidak lengkap dan tidak merata, maka model idealnya perlu menggunakan asumsi yang berbeda untuk negara yang berbeda.

\section{METODE PENELITIAN}

Menurut Masyrofie (1994), untuk melihat hubungan elastisitas harga di tingkat internasional dengan elastisitas harga di tingkat domestik (produsen dan konsumen), dilihat elastisitas transmisi harganya. Model yang digunakan adalah:

$$
\text { Pf }=\alpha \operatorname{Pr} \beta
$$

Kemudian model tersebut dirubah menjadi bentuk linear sebagai berikut:

$$
\text { Ln Pf }=\operatorname{Ln} \alpha+\beta \text { Ln Pr }
$$

Keterangan:

$\mathrm{Pf}=$ harga di tingkat domestik $(\mathrm{Rp} / \mathrm{kg})$;

$\operatorname{Pr}=$ harga di tingkat internasional

$(\mathrm{Rp} / \mathrm{kg})$;

$\alpha=$ intersep;

$\beta=$ koefisien
Penambahan variabel lain sangat dimungkinkan karena terdapat banyak variabel yang turut berpengaruh terhadap harga domestik selain harga internasional itu sendiri. Pengujian parameter dilakukan dengan uji $t$, dengan hipotesis sebagai berikut:

$$
\begin{array}{ll}
\text { H0 } & : \beta=1 \\
\text { H1 } & : \beta \neq 1
\end{array}
$$

Pengujian hipotesis:

$$
\text { t-hitung: } \frac{\beta-1}{\operatorname{SE}(\beta)}
$$

Dengan meningkatnya perdagangan, maka pengukuran transmisi harga seperti di atas dapat menimbulkan bias. Bias tersebut timbul dari asumsi bahwa harga domestik merupakan variabel yang dibentuk oleh harga dunia dan faktor-faktor lain yang mempengaruhinya.

Intensitas perdagangan yang lebih tinggi dengan adanya diferensiasi produk dan perubahan kebjakan perdagangan dan kebijakan industri memberikan peluang bagi suatu negara sebagai eksportir atau importir suatu komoditi. Dengan keunggulan komparatif dan keunggulan kompetitif, maka suatu negara eksportir atau importir dapat memiliki pasar yang lebih luas sehingga mempunyai kekuatan pasar. Dengan demikian, kondisi bahwa harga dunia dipengaruhi oleh harga domestik dapat terjadi.

Untuk itu, harga domestik yang disebutkan dalam studi ini adalah harga ekspor atau harga impor suatu komoditi. Harga ekspor atau harga impor diproksi dengan konsistensi nilai perdagangan bersih suatu komoditi. Jika nilai perdagangan bersih (ekspor dikurangi impor) Indonesia untuk suatu komoditi adalah surplus, maka Indonesia ditetapkan sebagai negara eksportir sedangkan jika nilai perdagangan bersih (ekspor dikurangi impor) Indonesia untuk suatu komoditi adalah defisit maka Indonesia ditetapkan sebagai negara importir.

Volume ekspor dan impor terkait komoditi cabai merah dan daging ayam ras adalah produk yang terkait dengan olahan cabai merah dan pembibitan ayam ras; untuk ikan segar komoditi utamanya adalah ikan tuna. Karena itu, harga produsen yang digunakan adalah harga yang diterima petani produsen atau bukan harga bersih dari transaksi ekspor impor produk cabe merah segar maupun pembibitan ayam. Untuk ikan segar, karena data yang 
tersedia adalah harga eceran ikan kembung, maka yang dianalisa adalah transmisi harga produsen dan harga eceran ikan kembung. Periode yang digunakan adalah Mei 2009 sampai dengan Desember 2013.

\section{HASIL DAN PEMBAHASAN}

\section{Cabai Merah}

Model persamaan analisis resesi antara harga di tingkat produsen dan harga di tingkat pengecer adalah sebagai berikut:

\section{Harga Produsen $=14.526,539+0,145$ Harga Eceran}

Hasil penelitian menunjukkan bahwa nilai koefiesien regresi $(\beta)$ kurang dari satu dan positif. Hal ini mengindikasikan bahwa kenaikan harga eceran meningkatkan harga di tingkat produsen dimana perubahan harga eceran sebesar Rp 1.000 akan merubah harga produsen sebesar Rp 145. Hal ini mengindikasikan bahwa pasar cabai merah tidak terintegrasi dengan sempurna. Pasar yang kurang terintegrasi dapat disebabkan oleh pola distribusi atau pemasaran sehingga kecenderungannya adalah oligopsoni.

Nilai elastisitas transmisi harga cabai merah yaitu 0,096 atau kurang dari satu yang artinya jika terjadi perubahan pada harga eceran $1 \%$ maka terjadi perubahan pada harga eceran sebesar 0,096\%. Dengan demikian, elastisitas transmisi harga bersifat inelastis. Nilai ini menunjukkan bahwa perubahan harga pada konsumen tidak tertransmisikan secara sempurna kepada produsen. Nilai yang positif juga mengindikasikan bahwa kenaikan harga eceran justru akan mendorong kenaikan harga produsen.

\section{Daging Ayam Ras}

Model persamaan analisis reresi antara harga di tingkat produsen dan harga di tingkat pengecer untuk daging ayam ras adalah sebagai berikut

\section{Harga Produsen=28.053,685 + 0,576 Harga Eceran}

Hasil penelitian menunjukkan bahwa nilai koefiesien regresi ( $\beta$ ) kurang dari satu dan positif. Hal ini mengindikasikan bahwa kenaikan harga eceran meningkatkan harga di tingkat produsen dimana perubahan harga eceran sebesar Rp1.000 akan merubah harga produsen sebesar Rp576. Hal ini mengindikasikan bahwa pasar daging ayam ras tidak terintegrasi dengan sempurna.

Nilai elastisitas transmisi harga yaitu 0,867 atau kurang dari satu yang artinya jika terjadi perubahan harga konsumen 1\% menyebabkan perubahan harga produsen $0,867 \%$. Dengan demikian, perubahan harga eceran tidak tertransmisikan secara sempurna ke harga produsen. Nilai yang positif mengindikasikan bahwa kenaikan harga eceran daging ayam ras mendorong kenaikan harga produsen.

\section{Ikan Segar}

Model persamaan analisis reresi antara harga di tingkat produsen dan harga di tingkat pengecer adalah sebagai berikut

Harga Produsen $=-43.098,337+2,708$ Harga Eceran

Hasil penelitian menunjukkan bahwa nilai koefiesien regresi $(\beta)$ lebih dari satu dan positif. Hal ini mengindikasikan bahwa kenaikan harga eceran meningkatkan harga di tingkat produsen dimana perubahan harga eceran sebesar Rp1.000 akan merubah harga produsen sebesar Rp2.708. Hal ini mengindikasikan bahwa pasar cabai merah tidak terintegrasi dengan sempurna.

Nilai elastisitas transmisi harga ikan segar yaitu 0,447 atau kurang dari satu yang artinya jika terjadi perubahan harga konsumen 1\% menyebabkan perubahan harga produsen 0,447\%. Dengan demikian, perubahan harga eceran tidak tertransmisikan secara sempurna ke harga produsen. Nilai yang positif mengindikasikan bahwa kenaikan harga eceran mendorong kenaikan harga produsen.

\section{SIMPULAN}

Inflasi harga pangan dalam negeri sangat terkait dengan nilai dari inflasi harga pangan global. Fluktuasi limpahan dari global untuk harga pangan dalam negeri tampaknya kontemporer. Gerakan tingkat inflasi harga pangan nasional dan fluktuasi sangat terkait dengan tingkat inflasi harga pangan intra dan ekstra-regional dan fluktuasi masing-masing. Selajutnya hal ini juga menunjukkan bahwa inflasi harga pangan global mempengaruhi 
pasar makanan nasional di seluruh wilayah tetapi dengan jeda waktu berbeda.

Kenaikan harga eceran meningkatkan harga di tingkat produsen yang mengindikasikan bahwa pasar cabai merah, daging ayam ras, dan ikan segar tidak terintegrasi dengan sempurna. Variasi perubahan harga eceran merupakan sumber variasi perubahan harga produsen dan memiliki hubungan yang signifikan antara harga di tingkat produsen dengan harga eceran. Perubahan harga eceran tidak tertransmisikan secara sempurna ke harga produsen dimana kenaikan harga eceran mendorong kenaikan harga produsen.

\section{DAFTAR PUSTAKA}

Baltzer, Kenneth. International to domestic price transmission in fourteen developing countries during the 2007-08 food crisis. WIDER Working Paper No. 2013/031 March 2013. University of Copenhagen.

Keats, Sharada. dkk. Food price transmission: rising international cereals prices and domestic markets, Project Briefing No. 48 October 2010. Overseas Development Institute. London.

Kementerian Perdagangan, 2013. Artikel Edisi 08 CABE/08/2013, Tinjauan Pasar Cabe, diunduh dari ews.kemendag.go.id.

Lee, Hyun-Hoon and Park, Cyn-Young. International Transmission of Food Prices and Volatilities: A Panel Analysis. $A D B$ Economics Working Paper Series No. 373 | September 2013. Asian Development Bank. Manila.

Minot, Nicholas. Transmission of World Food Price Changes to Markets in Sub-Saharan Africa. IFPRI Discussion Paper 01059 January 2011. Markets, Trade and Institutions Division International Food Policy Research Institute.

Pusat Data dan Sistem Informasi Pertanian Sekretariat Jenderal Kementerian Pertanian, Statistik Harga Komoditas Pertanian Tahun 2013, diunduh dari pusdatin.setjen.pertanian.go.id.

Pusat Sosial Ekonomi dan Kebijakan PertanianBalitbang Pertanian Kementerian Pertanian, Outlook Pertanian 2010-2025.

Weinhagen, Jonathan C. Price transmission effects through three stages of food production. Monthly Labor Review December 2012. US Department of Labor. Price transmission: from crude petroleum to plastics product. Monthly Labor Review December 2006. US Department of Labor.

World Bank. Transmission of Global Food Prices to Domestic Prices in Developing Countries: Why It Matters, How It Works, and Why It Should Be Enhanced. Contribution from the World Bank to the G20 Commodity Markets Sub Working Group. April 2012. 